CENDEKIA, Vol. 9, No. 1, April 2015

p ISSN: 1978 2098; e ISSN: 2407 8557; Web: cendekia.pusatbahasa.or.id

Pusat Kajian Bahasa dan Budaya, Surakarta, Indonesia

Beatrik, S. Rissa. 2015. Penggunaan Model Permainan Susun Gambar

Dalam Menulis Kalimat Siswa SD Kelas 3. Cendekia, 9(1): 113 122.

\title{
PENGGUNAAN MODEL PERMAINAN SUSUN GAMBAR DALAM MENULIS KALIMAT SISWA SD KELAS 3
}

\author{
Rissa Beatrik S \\ Program Pascasarjana \\ Universitas Negeri Malang \\ Jl. Surabaya No. 6 Malang \\ Email: bosten.sidabutar@yahoo.com
}

\begin{abstract}
This paper describes model of teaching writing for elementary school students using Picture and Picture techniques. As to write a complete sentence in Bahasa Indonesia, is the core competency for elementary school students in the grade 3 according to 2013 Curriculum for SD, model of appropriate teaching is required to explore. This model is a response to alternate conventional methods to accomplish Standardized Competency. This model promotes games-based interactive model to arouse writing sentences in a competition rules and drive interest to students.
\end{abstract}

Keywords: picture and pictures, writing literacy.

Model pembelajaran merupakan salah satu komponen penting yang menunjang keberhasilan proses pembelajaran. Ketepatan pemilihan model pembelajaran akan berdampak pada keberhasilan belajar siswa serta tercapainya tujuan pembelajaran. Model pembelajaran merupakan "suatu desain pembelajaran yang dirancang untuk memperlancar proses pembelajaran". Seperti yang diungkapkan oleh Suprijono (2012:46) yang mengemukakan bahwa model pembelajaran ialah pola yang digunakan sebagai pedoman dalam merencanakan pembelajaran di kelas maupun tutorial. Dari pengertian model pembelajaran tersebut, model pembelajaran dapat dipahami sebagai suatu desain, pola atau rancangan yang digunakan sebagai pedoman dalam merencanakan pembelajaran di kelas.

Hal itu dilakukan untuk menciptakan suasana yang menunjang agar siswa merasa bebas untuk merespon secara alami dan teratur, sehingga tujuan pembelajaran dapat tercapai dengan baik. Karena itu, pengkajian pemilihan model pembelajaran yang tepat menjadi hal yang perlu dilakukan, agar sesuai dengan karakteristik siswa dan pembelajaran yang akan dilaksanakan. Dalam pembelajaran bahasa Indonesia di sekolah tujuan pembelajaran yang hendak dicapai sejatinya difokuskan pada empat keterampilan berbahasa yaitu menyimak, membaca, menulis dan berbicara. Setiap keterampilan erat sekali berhubungan dengan proses-proses yang mendasari bahasa.

Begitu juga dalam poses pembelajaran bahasa Indonesia, pembelajaran pada salah satu aspek keterampilan bahasa tersebut akan saling mempengaruhi keterampilan berbahasa yang lain pada proses belajar mengajar. Proses belajar-mengajar di sekolah melibatkan banyak factor. Dapat dijelaskan bahwa masukan yang merupakan bahan dasar diberikan pengalaman 
CENDEKIA, Vol. 9, No. 1, April 2015

p ISSN: 1978 2098; e ISSN: 2407 8557; Web: cendekia.pusatbahasa.or.id

Pusat Kajian Bahasa dan Budaya, Surakarta, Indonesia

Beatrik, S. Rissa. 2015. Penggunaan Model Permainan Susun Gambar

Dalam Menulis Kalimat Siswa SD Kelas 3. Cendekia, 9(1): 113 122.

belajar tertentu dalam proses belajar-mengajar, dengan harapan dapat berubah menjadi keluaran yang berupa hasil belajar yang diharapkan.

Pada saat proses belajar mengajar maka akan terjadi hubungan timbal balik antara guru dan siswa yang beraneka ragam, dan itu akan mengakibatkan terbatasnya waktu guru untuk mengontrol bagaimana pengaruh tingkah lakunya terhadap motivasi belajar siswa. Hal tersebut memperkuat anggapan bahwa guru dituntut untuk lebih kreatif dalam proses belajar mengajar, sehingga tercipta suasana belajar yang menyenangkan pada diri siswa yang pada akhimya meningkatkan motivasi belajar siswa.

Berdasarkan pengalaman dan pengamatan di kelas, ditemukan bahwa menulis kerap kali menjadi suatu hal yang kurang diminati dan kurang mendapat respon yang baik dari siswa. Siswa tampak mengalami kesulitan ketika harus menulis. Siswa tidak tahu apa yang harus dilakukan ketika pembelajaran menulis dimulai. Mereka terkadang sulit sekali menggunakan ejaan yang tepat di dalam karangan. Siswa kerap mengalami sindrom kertas kosong, tidak tahu apa yang harus ditulisnya. Mereka takut salah, takut berbeda dengan apa yang diinstruksikan gurunya.

Keterampilan menulis di kelas terkadang juga hanya diajarkan pada saat pembelajaran menulis saja, padahal pembelajaran keterampilan menulis dapat dipadukan dalam setiap proses pembelajaran di kelas. Perpaduan tersebut dapat bersifat internal dan eksternal. Internal berarti pembelajaran menulis diintegrasikan dalam pembelajaran keterampilan berbahasa yang lain. Secara eksternal dengan mata pelajaran lain di luar mata pelajaran bahasa Indonesia, sehingga Perlu adanya model pembelajaran alternatif untuk memotivasi siswa yaitu model pembelajaran baca gambar.

Agar materi menulis kalimat tidak terkesan membosankan maka dalam makalah ini dibuat pembelajaran menulis kalimat melalui model pembelajaran susun gambar. Sehingga pembelajaran tersebut diharapkan bisa lebih menarik untuk dipahami siswa, yang berdampak pada keaktifan siswa dalam mengikuti pembelajaran serta pemahaman siswa yang baik akan penulisan kalimat.

Strategi pembelajaran susun gambar yang merangsang tingkat kognitif siswa untuk membuat kalimat, sehingga nantinya bisa mengarahkan siswa untuk mampu menbuat karangan yang utuh.

\section{MODEL PEMBELAJARAN}

Model pembelajaran susun gambar dikembangkan dari model pembelajaran picture and picture yang merupakan salah satu model yang dapat mendorong siswa untuk lebih aktif dalam pembelajaran. Kunandar (2010:371) menyatakan bahwa pembelajaran picture and picture adalah kegiatan pembelajaran di mana siswa didorong untuk belajar melalui keterlibatan aktif mereka sendiri dengan konsep-konsep dan prinsip-prinsip dan guru mendorong siswa untuk memiliki pengalaman dan melakukan percobaan yang memungkinkan siswa menemukan prinsip-prinsip untuk diri mereka sendiri.

Model pembelajaran susun gambar adalah rangkaian kegiatan pembelajaran yang menekankan pada proses berpikir secara kritis dan analitis untuk mencari dan menemukan sendiri jawaban dari suatu masalah yang dipertanyakan.

Model susun gambar dikembangkan dari model picture and picture yaitu model yang menggunakan gambar dan dipasangkan atau diurutkan menjadi urutan logis. Model 
pembelajaran ini mengandalkan gambar yang menjadi faktor utama dalam proses pembelajaran. Maka dari itu, sebelumnya guru sudah menyiapkan gambar yang akan ditampilkan, baik dalam bentuk kartu atau carta dalam ukuran besar.

Gambar sangat penting digunakan untuk memperjelas pengertian. Melalui gambar, siswa mengetahui hal-hal yang belum pernah dilihatnya. Gambar dapat membantu guru mencapai tujuan intruksional karena selain merupakan mediayang murah dan mudah diperoleh, juga dapat meningkatkan keaktifan siswa. Selain itu, pengetahuan dan pemahaman siswa menjadi lebih luas, jelas dan tidak mudah dilupakan.

Model apapun yang digunakan selalu menekankan keaktifan peserta didik dalam setiap proses pembelajaran. Cirinya adalah inovatif dan kreatif.

\section{Karakteristik atau model pembelajaran susun gambar}

a. Menuntut siswa untuk bertanggung jawab mengerjakan tugas dalam kelompok.

b. Setiap anggota menyadari tujuan yang sama

c. Setiap anggota menyadari tanggung jawab yang sama dalam kelompok

d. Setiap kelompok belajar bersama dalam anggota kelompoknya

e. Setiap anggota dituntut untuk belajar secara kooperatif untuk mencapai tujuan bersama.

\section{Langkah-langkah Model Pembelajaran Susun Gambar}

Adapun langkah-langkah dari pelaksanaan Susun Gambar ini terdapat tujuh langkah yaitu:

a. Guru menyampaikan kompetensi yang ingin dicapai.

Pada langkah ini guru menyampaikan apa yang menjadi Kompetensi Dasar mata pelajaran yang bersangkutan. Dengan demikian maka siswa dapat mengukur sampai sejauh mana yang harus dikuasainya. Disamping itu guru juga harus menyampaikan indikator-indikator ketercapaian KD, sehingga sampai dimana KKM yang telah ditetapkan dapat dicapai oleh peserta didik.

b. Menyajikan materi sebagai pengantar

Guru memberikan pemodelan pembelajaran dan memberikan motivasi yang menarik perhatian siswa yang belum siap. Dengan motivasi dan teknik yang baik dalam pemberian materi akan menarik minat siswa untuk belajar lebih jauh tentang materi yang dipelajari.

c. Guru menunjukkan/memperlihatkan gambar-gambar yang berkaitan dengan materi "Pola Hidup Sehat".

d. Dalam proses penyajian materi, guru mengajak siswa ikut terlibat aktif dalam proses pembelajaran dengan mengamati setiap gambar yang ditunjukan oleh guru atau oleh temannya. Dengan gambar kita akan memotivasi siswa untuk tertarik memahami materi yang diajarkan. Selanjutnya guru memodifikasikan gambar dalam bentuk potonganpotongan yang tidak utuh.

e. Kemudian guru menunjuk/memanggil siswa secara bergantian untuk memasang/mengurutkan gambar-gambar menjadi urutan yang logis dengan cara mengundi, sehingga siswa merasa memang harus menjalankan tugas yang harus diberikan. Gambar-gambar yang sudah ada diminta oleh siswa untuk diurutkan, dibuat, atau di modifikasi menjadi gambar yang utuh. 
CENDEKIA, Vol. 9, No. 1, April 2015

p ISSN: 1978 2098; e ISSN: 2407 8557; Web: cendekia.pusatbahasa.or.id

Pusat Kajian Bahasa dan Budaya, Surakarta, Indonesia

Beatrik, S. Rissa. 2015. Penggunaan Model Permainan Susun Gambar

Dalam Menulis Kalimat Siswa SD Kelas 3. Cendekia, 9(1): 113 122.

f. Kemudian siswa diminta untuk menuliskan 5 kalimat berdasarkan urutan gambar yang sudah disusun secara utuh. Hal ini untuk melatih siswa dalam mengemukan alasan pemikiran atau pendapat tentang urutan gambar tersebut. Dalam langkah ini peran guru sangatlah penting sebagai fasilitator dan motivator agar siswa berani mengemukakan pendapatnya.

g. Dari alasan/urutan gambar tersebut, guru mulai menanamkan konsep atau materi, sesuai dengan kompetensi yang ingin dicapai.

h. Dalam proses ini guru harus memberikan penekanan-penekanan pada hal ingin dicapai dengan meminta siswa lain untuk mengulangi, menuliskan atau bentuk lain dengan tujuan siswa mengetahui bahwa hal tersebut penting dalam pencapaian KD dan indikator yang telah ditetapkan. Pastikan bahwa siswa telah menguasai indikator yang telah ditetapkan.

i. Siswa diajak untuk menyimpulkan/merangkum materi yang baru saja diterimanya. Kesimpulan dan rangkuman dilakukan bersama dengan siswa. Guru membantu dalam proses pembuatan kesimpulan dan rangkuman. Apabila siswa belum mengerti hal-hal apa saja yang harus diperhatikan dalam pengamatan gambar tersebut guru memberikan penguatan kembali tentang gambar tersebut.

\section{Kelebihan}

a. Materi yang diajarkan lebih terarah karena pada awal pembelajaran guru menjelaskan kompetensi yang harus dicapai dan materi secara singkat terlebih dahulu.

b. Siswa lebih cepat menangkap materi ajar karena guru menunjukkan gambar-gambar mengenai materi yang dipelajari.

c. Siswa dapat membaca satu per satu sesuai petunjuk yang ada pada gambar-gambar yang diberikan

d. Siswa lebih berkonsentrasi dan merasa asyik karena tugas yang diberikan oleh guru berkaitan dengan permainan mereka sehari-hari, yakni bermain gambar.

e. Adanya saling kompetisi antarkelompok dalam menyusun gambar yang telah dipersiapkan oleh guru sehingga suasana kelas lebih hidup.

f. Pembelajaran lebih berkesan dan mudah diingat, sebab siswa dapat mengamati langsung gambar yang telah dipersiapkan oleh guru.

\section{Kekurangan}

a. Memakan banyak waktu

b. Banyak siswa yang pasif

c. Harus mempersiapkan banyak alat dan bahan yang berhubungan dengan materi yang akan diajarkan dengan model tersebut.

d. Guru khawatir akan terjadi kekacauan di kelas.

e. Membutuhkan biaya yang tidak sedikit.

\section{Keefektifan Strategi Pembelajaran Susun Gambar}

Model Pembelajaran susun gambar efektif apabila: 
a. Guru mengharapkan siswa dapat menemukan sendiri jawaban dari suatu permasalahan yang ingin dipecahkan.

b. Jika proses pembelajaran berangkat dari ingin tahu siswa terhadap sesuatu.

c. Jika akan mengajar pada sekelompok siswa yang memiliki kemampuan berpikir di atas rata-rata.

d. Jika siswa yang belajar tak terlalu banyak sehingga bisa dikendalikan oleh guru.

e. Jika guru memiliki waktu yang cukup untuk menggunakan pendekatan yang berpusat pada siswa.

\section{Langkah Pembelajaran menulis pembelajaran Susun Gambar.}

\section{Menjawab pertanyaan}

Siswa diminta untuk mengamati potongan gambar "Lawan Kuman dengan Mencuci Tangan" lalu mengurutkan gambar sesuai prosedurnya.

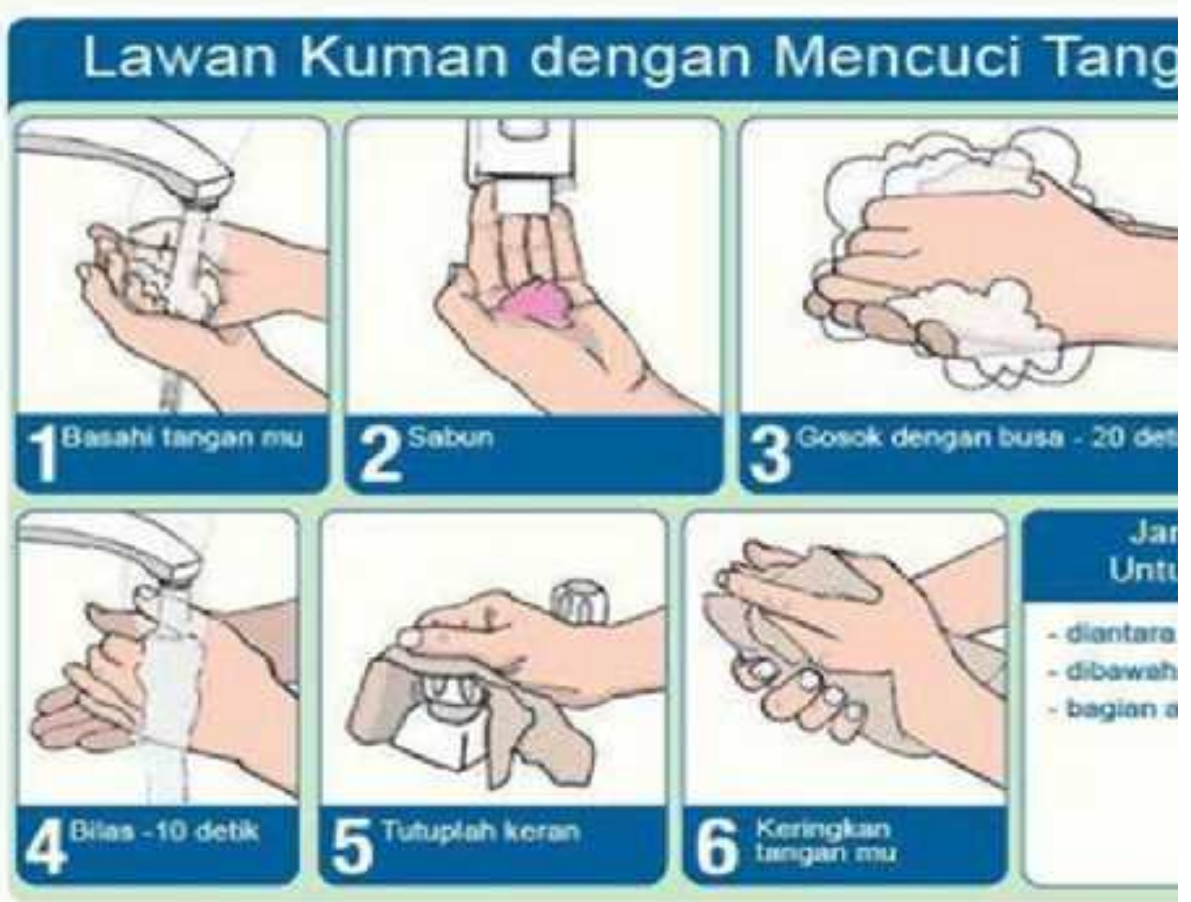




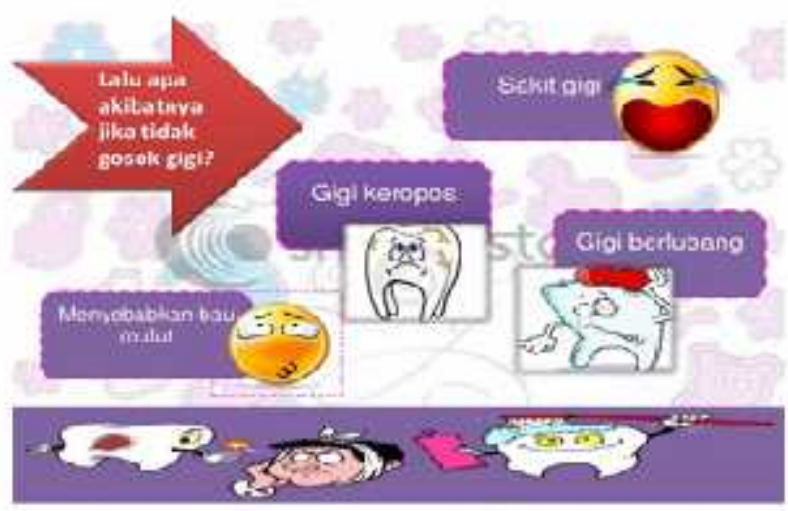

\section{Melengkapi kalimat pertanyaan}

Siswa diminta untuk menyusun kalimat pertanyaan sesuai dengan kata tanya yang tepat berdasarkan ilustrasi gambar.

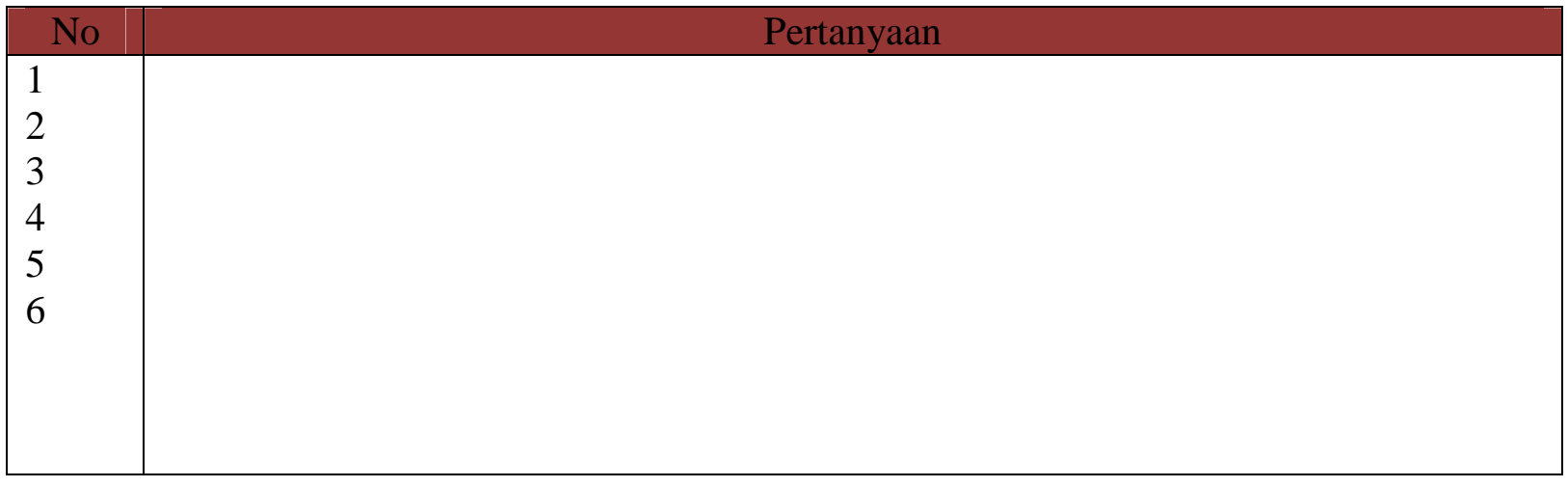

3. menyusun dan menulis kalimat berdasarkan jawaban gambar yang telah disusun.

4. menulis karangan sederhana dengan memperhatikan penggunaan huruf kapital dan tanda titik.

5. Menulis Kalimat dengan memperhatikan pemakaian huruf kapital

Menurut Resmini, dkk. (2006:311) menulis merupakan kemampuan berbahasa tulis dan sebagai salah satu dari empat keterampilan berbahasa (skills). Menulis ditandai oleh serangkaian kegiatan yang bertahap, saat seorang mengomunikasikan pesan ke dalam tulisan. Pesan itu dapat berupa ide, kemauan, keinginan, perasaan, ataupun informasi yang bersumber dari diri sendiri (skemata), maupun lingkungan atau di luar dai diri sendiri. Tulisan itu berasal dari hasil pemaduan aspek komunikasi menjadi symbol-simbol (grafonis) yang dapat dibaca. Menulis kalimat sekurang-kurangnya harus memiliki subjek dan predikat. 


\section{Pendekatan dan Metode Pembelajaran}
a. Pendekatan
: Scientific
b. Model
: Susun Gambar

\section{Media, Alat, dan Sumber Pembelajaran \\ Media:}

Gambar ilustrasi, puzzle potongan gambar

Alat membangun konteks

Teks "Pola Hidup Bersih dan Sehat"

\section{Langkah-langkah Kegiatan Pembelajaran \\ Pendahuluan (10 MENIT)}

a. Guru membangun hubungan dengan peserta didik

b. Guru membangun konteks (memberi stimulus berupa pertanyaan yang akan ditemukan dalam teks "Ayo Selamatkan Bumi")

c. Peserta didik mengamati gambar - gambar pola Hidup Bersih dan Sehat

d. Peserta didik bertanya dengan kata tanya $5 \mathrm{~W}+1 \mathrm{H}$ tentang Pola Hidup Bersih dan Sehat.

e. Guru menyampaikan tujuan pembelajaran dan manfaat mempelajari KD.

f. Guru menyampaikan langkah-langkah kegiatan yang akan ditempuh untuk mencapai kompetensi.

g. Pendidik menyampaikan tujuan pembelajaran yang akan dilakukan.

h. Pendidik dan peserta didik menyepakati langkah-langkah kegiatan yang akan ditempuh untuk mencapai kompetensi.

\section{Pelaksanaan}

Periksa fase pelaksanaan dalam tabel di bawah

\section{Penutup (10 menit)}

1) Peserta didik mengemukakan kesulitan dan kemanfaatan selama pembelajaran berlangsung.

2) Peserta didik menyampaikan usulan untuk perbaikan pembelajaran berikutnya

3) Peserta didik menerima tugas mencari Perilaku Hidup Bersih dan Sehat. 
Fase Pelaksanaan Pembelajaran

\begin{tabular}{|c|c|}
\hline FASE-FASE & KEGIATAN PEMBELAJARAN \\
\hline $\begin{array}{l}\text { Fase } 1 \\
\text { Orientasi peserta } \\
\text { didik kepada } \\
\text { masalah }\end{array}$ & $\begin{array}{l}\text { Kegiatan Inti } \\
\text { 1. Guru menjelaskan tujuan pembelajaran } \\
\text { 2. Peserta didik mengamati gambar Perilaku Hidup Bersih } \\
\text { dan Sehat } \\
\text { 3. Peserta didik menentukan masalahnya misalnya } \\
\text { a. Gambar tersebut menceritakan apa? } \\
\text { b. Mengapa perlu menjaga Perilaku Hidup Bersih } \\
\text { dan Sehat? Bagaimana caranya agar teks } \\
\text { berdasarkan gambar tersebut menjadi sebuah } \\
\text { teks yang utuh? }\end{array}$ \\
\hline $\begin{array}{l}\text { Fase } 2 \\
\text { Mengorganisasikan } \\
\text { peserta didik }\end{array}$ & $\begin{array}{l}\text { 1. Guru membantu peserta didik mendefinisikan dan } \\
\text { mengorganisasikan tugas belajar yang berhubungan } \\
\text { dengan masalah tersebut. } \\
\text { 2. Guru meminta peserta didik membentuk kelompok } \\
\text { kecil. } \\
\text { 3. Peserta didik membaca informasi dan merancang } \\
\text { jawaban sementara yang bersifat dugaan sementara yang } \\
\text { berisi tentang alternatif-alternatif strategi yang } \\
\text { digunakan untuk memecahkan masalah, yaitu terkait } \\
\text { Perilaku Hidup Bersih dan Sehat. }\end{array}$ \\
\hline $\begin{array}{l}\text { Fase } 3 \\
\text { Membimbing } \\
\text { penyelidikan } \\
\text { individu dan } \\
\text { kelompok }\end{array}$ & $\begin{array}{l}\text { 1. Guru mendorong peserta didik untuk mengumpulkan } \\
\text { informasi yang sesuai dan melaksanakan observasi untuk } \\
\text { mendapatkan data yang diperlukan untuk menyelesaikan } \\
\text { masalah } \\
\text { 2. Peserta didik mengumpulkan informasi untuk } \\
\text { menciptakan dan membangun ide mereka sendiri dalam } \\
\text { memecahkan masalah. } \\
\text { 4. Pada kegiatan ini peserta didik mendiskusikan materi } \\
\text { dengan membaca teks Perilaku Hidup Bersih dan } \\
\text { Sehat. }\end{array}$ \\
\hline $\begin{array}{l}\text { Fase } 4 \\
\text { Mengembangkan } \\
\text { dan menyajikan } \\
\text { hasil karya }\end{array}$ & $\begin{array}{l}\text { 1. Data yang sudah terkumpul dianalisis sesuai dengan } \\
\text { permasalahan yang terdapat dalam teks Perilaku } \\
\text { Hidup Bersih dan Sehat. } \\
\text { 2. Data yang telah dianalisis kemudian dikelompokkan } \\
\text { berdasarkan kategori permasalahan yang telah } \\
\text { dirumuskan. }\end{array}$ \\
\hline
\end{tabular}


CENDEKIA, Vol. 9, No. 1, April 2015

p ISSN: 1978 2098; e ISSN: 2407 8557; Web: cendekia.pusatbahasa.or.id

Pusat Kajian Bahasa dan Budaya, Surakarta, Indonesia

Beatrik, S. Rissa. 2015. Penggunaan Model Permainan Susun Gambar

Dalam Menulis Kalimat Siswa SD Kelas 3. Cendekia, 9(1): 113 122.

\begin{tabular}{|l|l|}
\hline \multicolumn{1}{|c|}{ FASE-FASE } & \multicolumn{1}{c|}{ KEGIATAN PEMBELAJARAN } \\
\hline & $\begin{array}{l}\text { 3. } \\
\text { Peserta didik harus memberikan argumentasi } \\
\text { terhadap jawaban dari masalah yang ada dalam } \\
\text { bentuk tulisan. }\end{array}$ \\
\hline $\begin{array}{l}\text { Fase 5 } \\
\text { Menganalisa dan } \\
\text { mengevaluasi } \\
\text { proses pemecahan } \\
\text { masalah }\end{array}$ & $\begin{array}{l}\text { 1. } \begin{array}{l}\text { Guru bersama peserta didik menganalisis dan } \\
\text { mengevaluasi terhadap proses pemecahan masalah } \\
\text { yang dipresentasikan setiap kelompok maupun } \\
\text { terhadap seluruh aktivitas pembelajaran yang } \\
\text { dilakukan. }\end{array} \\
\text { 2. Guru memberikan penguatan (mengasosiasi) terkait } \\
\text { penguasaan pengetahuan atau konsep tertentu, } \\
\text { misalnya struktur teks Perilaku Hidup Bersih dan } \\
\text { Sehat }\end{array}$ \\
\hline
\end{tabular}

\section{SIMPULAN}

Model pembelajaran susun gambar adalah model pembelajaran yang mempersiapkan siswa pada situasi untuk melakukan eksperimen sendiri sehingga dapat berpikir secara kritis untuk mencari dan menemukan jawaban dari suatu masalah yang dipertanyakan. Sasaran utama kegiatan pembelajaran susun gambar adalah keterlibatan siswa secara maksimal dalam proses kegiatan belajar, keterarahan kegiatan secara maksimal dalam proses kegiatan belajar, mengembangkan sikap percaya pada diri siswa tentang apa yang ditemukan dalam proses susun gambar. Namun dalam penerapannya, pembelajaran susun gambar ini memiliki kelemahan seperti adanya kesulitan dalam mengontrol siswa, ketidaksesuaian kebiasaan siswa dalam belajar, kadang memerlukan waktu yang panjang dalam pengimplementasiannya, dan sulitnya dalam implementasi yang dilakukan oleh guru bila keberhasilan belajar bergantung pada siswa.

Teori-teori yang melandasi model pembelajaran susun gambar yaitu teori belajar kontrukstivisme, teori belajar Ausubel, teori belajar penemuan oleh Gagne. Langkah-langkah pembelajaran Susun Gambar adalah sebagai berikut orientasi, merumuskan masalah, merumuskan hipotesis, mengumpulkan data, menguji hipotesis, merumuskan kesimpulan. Model pembelajaran Susun Gambar mengandung proses-proses mental yang lebih tinggi tingkatannya, misalnya merumuskan problema sendiri, merancang eksperimen sendiri, melakukan eksperimen sendiri, mengumpulkan dan menganalisis data, menarik kesimpulan, mempunyai sikap-sikap obyektif, jujur, hasrat ingin tahu, terbuka, dan sebagainya.

\section{DAFTAR PUSTAKA}

Gautama, P. 2010. Tangram: Melatih Kecerdasan dan Kreativitas Anak Edisi: Burung \& Kucing. Jakarta: Elex Media Komputindo.

Joyce, bruce dkk. 2009. Models of Teaching Model-Model Pengajaran. Yogyakarkata: Pustaka Pelajar.

Kunandar. 2007. Guru Professional Implementasi Tingkat Satuan Pendidikan (KTSP) Dan Sukses Dalam Sertifikasi Guru . Jakarta : Raja Grafindo. 
CENDEKIA, Vol. 9, No. 1, April 2015

p ISSN: 1978 2098; e ISSN: 2407 8557; Web: cendekia.pusatbahasa.or.id

Pusat Kajian Bahasa dan Budaya, Surakarta, Indonesia

Beatrik, S. Rissa. 2015. Penggunaan Model Permainan Susun Gambar

Dalam Menulis Kalimat Siswa SD Kelas 3. Cendekia, 9(1): 113 122.

Mulyasa. 2008. Menjadi guru Professional Menciptakan Pembelajaran Kreatif Dan Menyenangkan Bandung: Remaja Rosda Karya.

Shoimin, Aris. 2014. 68 Model Pembelajaran Inovatif dalam Kurikulum 2013. Yogyakarta : Ar-Ruzz Media.

Edu. 2002. Teori Belajar yang Mendasari Model Pembelajaran Picture and Picture.( Online). (http://repository.upi.edu/operator/upload/s_tm_054161_chapter2.pdf diakses pada 20 Januari 2015).

"Model Pembelajaran Inquiri". Online. (http://www.ras-eko.com/2011/05/model-pembelajaraninquiry.html diakses pada 20 Januari 2015) 